\title{
DETERMINATION OF CHLOROPHYLL AND CAROTENOIDS PRESENT IN THE SEEDS OF THE PLANT FAMILY APIACEAE AND THE IMPACT ON SEED QUALITY
}

\author{
Marie Grulichová1, Peter Mendel ${ }^{1}$, Václav Trojan ${ }^{1}$, Tomáš Vyhnánek ${ }^{1}$ \\ ${ }^{1}$ Department of Plant Biology, Faculty of AgriSciences, Mendel University in Brno, Zemědělská 1, 61300 Brno, \\ Czech Republic
}

\begin{abstract}
GRULICHOVÁ MARIE, MENDEL PETER, TROJAN VÁCLAV, VYHNÁNEK TOMÁŠ. 2018. Determination of Chlorophyll and Carotenoids Present in the Seeds of the Plant Family Apiaceae and the Impact on Seed Quality. Acta Universitatis Agriculturae et Silviculturae Mendelianae Brunensis, 66(4): 859-869.

In this study, we assessed the content of chlorophyll $a$ and $b, \beta$-carotene and lutein in seeds of carrot, celery, dill, parsley and parsnip commercial varieties by spectrophotometric method. It was determined that the content of chlorophyll $a$ was higher than chlorophyll $b$ and both differed significantly between plant species and varieties. The highest amounts of chlorophyll $a$, chlorophyll $b, \beta$-carotene and lutein were detected in parsley "Olomoucka dlouha". The lowest amounts of chlorophyll $a$, chlorophyll $b$, $\beta$-carotene and no lutein were detected in celery "Nuget", however, very low amount of lutein was detected in the parsley cultivars "Atika" and "Orbis". The content of $\beta$-carotene was higher than that of lutein in most varieties. The individual pigment contents were compared to seed quality parameters such as standard laboratory germination and seedling emergence. Negative correlation between energy of germination and pigments and positive correlation between seedling emergence and pigments in the parsnip and parsley varieties was observed. Determination the content of pigments and correlations observed the possibility to use spectrophotometry to evaluate the pigments present in the seeds as an indicator of seed quality.
\end{abstract}

Keywords: Apiaceae, carotenoids, chlorophylls, seed quality, spectrophotometry

\section{INTRODUCTION}

Seeds are important to the plant as a major means of reproduction and to humans and animals as a major source of food. Seeds are storage reserves of protein, starch and oil that are utilized by the plant during development and maturation (Bewley et al., 2013). In addition, chlorophyll that is present in the seed is partially broken down during seed development (Ward et al., 1994a). Chlorophyll $a$ is present in appreciable quantities in the testa of physiologically mature seeds that is photosynthetically inactive. The chlorophyll content is related not only to the seed maturity, but also to seed quality, because decline in chlorophyll fluorescence (CF) signal directly related to the germination performance under laboratory and greenhouse conditions, which is particularly important for the seed industry as an indicator for seed maturity and quality (Jalink et al., 1999).

Determination of the content of chlorophyll in seeds can be done by nondestructive or destructive methods. A non-destructive technique to determine the content of chlorophyll $a$ in the seed coat is based on measuring of the CF signals from intact seeds. This method is a highly sensitive and rapid and has been used in seeds of various plant species such as cabbage (Brassica oleracea L.) (Jalink et al., 
1998), tomato (Solanum lycopersicum L.) (Jalink et al., 1999), cucumber (Cucumis sativus L.) (Jing et al., 2000), barley (Hordeum vulgare L.) (Konstantinova et al., 2002), carrot (Daucus carota L.) (Groot et al., 2006), soybean (Glycine $\max$ L.) (Cicero et al., 2009), cantaloupe (Cucumis melo L.) (Wilson et al., 2014) and pepper (Capsicum annuum L.) (Kenanoglu et al., 2013; Kenanoglu et al., 2016).

A frequently used destructive method to determine the content of chlorophylls in seeds is high-performance liquid chromatography (HPLC). This method is very expensive and much more time-consuming, but it can be used to characterize chlorophyll composition - chlorophyll $a$, chlorophyll $b$, pheophytin $a$, pheophytin $b$, etc. (Ward et al., 1994b; Sinnecker et al., 2005; Borrmann et al., 2009). In addition, carotenoid content, such as $\beta$-carotene and lutein, can be determined simultaneously using HPLC as e.g. in soybean seeds (Monma et al., 1994).

The use of spectrophotometry to measure chlorophyll in seeds is another commonly used destructive methods. This detection method is very simple and fast, but depends on the selection of suitable extraction solvent for the seed sample and adequate wavelength of the absorption peak. Canola seeds (Brassica napus L.) were analyzed either by extracting chlorophyll in $3: 1$ isooctane/ethanol and wavelengths 625.5, 665.5, and $705.5 \mathrm{~nm}$ to measure the absorption peak for chlorophyll a (Ward et al., 1994a; Ward et al., 1995), or 95\% acetone as a solvent and wavelengths 645, 652 and $663 \mathrm{~nm}$ (Green et al., 1998) were used. In soybean seeds a mixture of 3:1 heptane/ethanol with later addition of diethyl ether and wavelengths of 660 and $642.5 \mathrm{~nm}$ were used for total chlorophyll content determination (Sinnecker et al., 2002). The amount of chlorophyll together with carotenoids were determined from a sample of flaxseed oil that was fully dissolved in cyclohexane and read at a maximum absorption of $670 \mathrm{~nm}$ for chlorophyll - pheophytin and at a maximum absorption of $470 \mathrm{~nm}$ for carotenoid - lutein (Herchi et al., 2011). Recently, the method of spectrophotometric measurement of different types of chlorophyll and carotenoids in extracts from seeds was modified. The pigments were extracted in a $3: 1$ petroleum ether/tetrahydrofuran (PE:THF) solution and were measured at maximum absorption of $645,655 \mathrm{~nm}$ for the determination of chlorophyll $a$ and chlorophyll $b$ content and at maximum absorption of 480 and $495 \mathrm{~nm}$ for the determination of $\beta$-carotene and lutein content (Bulda et al., 2008; Smolikova et al., 2011).

Seed quality is evaluated based on standard laboratory germination tests that are accepted by the International Seed Testing Association (ISTA), and is a routinely used in laboratories of seed production. Germination is defined as "the emergence and development of the seedling to a stage where the aspect of its essential structures indicates whether or not it is able to develop further into a satisfactory plant under favorable conditions in soil" (ISTA, 1996). The germination test shows the percentage of normal seedlings, abnormal seedlings, and dead/non-germinated seeds in a seed lot. The advantages of these methods are that they are repeatable and relatively low in cost to perform. However, the disadvantages are that trained personnel are needed, as well as a suitable and equipped space and long time to achieve results. Another disadvantage of these tests can be seen in possible differences in results between laboratory germination and field emergence/germination rates.

In this study it will be verified, whether it is possible to determine the pigment contents, namely chlorophylls - chlorophyll $a$, chlorophyll $b$, and carotenoids - $\beta$-carotene, lutein in the seeds of commercial varieties from the plant family Apiaceae using a simple spectrophotometric method. In addition, the correlation between the pigment contents in species and varieties and the seed quality parameters such as the standard laboratory germination, and seedling emergence will be investigated.

\section{MATERIALS AND METHODS}

Determination of the content of chlorophylls and carotenoids was performed in the seeds of four varieties of carrot (Daucus carota L.) - Jitka, Jolana, Marion, Olympus, four varieties of celery (Apium graveolens L.) - Albin, Jemny, Malachit, Nuget, four varieties of dill (Anethum graveolens L.) - Hanak, Monarch, Moravan, Oliver, three varieties of parsley (Petroselinum crispum L.) - Atika, Olomoucka dlouha, Orbis and three varieties of parsnip (Pastinaca sativa L.) - Albion, Bielas, Dlouhy bily, harvested in 2016. The seeds were provided by the seed companies SEMO, Smrzice and MORAVOSEED CZ, Mikulov. It can be supposed that seed companies provided seeds harvested at full maturity.

\section{Extraction and spectrophotometric measurement of chlorophylls and carotenoids}

Seed samples (500 mg) were ground in a laboratory mill (Analysette 3 SPARTAN, Fritsch) for 4-8 minutes. The homogenate was mixed with $2 \mathrm{ml}$ of a 1:1 mixture of petroleum ether (PE $60-80^{\circ} \mathrm{C}$, pure) and tetrahydrofuran (THF). A total of $3 \mathrm{ml}$ of $\mathrm{PE}$ was then added to the solution. The sample was rinsed 2 times with $3 \mathrm{ml}$ of PE : THF (4:1) mixture. The homogenate was then filtered through a syringe containing nylon filters (polyamide) with a pore size of $0.45 \mu \mathrm{m}$. The obtained filtrate was used to measure chlorophyll $a$, chlorophyll $b, \beta$-carotene and lutein using a spectrophotometer (Spectronic 20 Genesys, Thermo Scientific). Chlorophyll $a$ and chlorophyll $b$ were measured at wavelengths 645 and $655 \mathrm{~nm}$, $\beta$-carotene and lutein at wavelengths 480 and $495 \mathrm{~nm}$. Each sample measurement was performed in three replicates and the pigment content was calculated from equations presented by Bulda et al., (2008): 
$\mathrm{C}_{a}=19.00 \mathrm{~A}_{655}-7.61 \mathrm{~A}_{645}$

$C_{b}=21.45 \mathrm{~A}_{645}-5.92 \mathrm{~A}_{655}$

where $\mathrm{A}$ is absorption of the solution at 645 and $655 \mathrm{~nm}, \mathrm{C}_{a}$ is the concentration of chlorophyll $a(\mathrm{mg} / \mathrm{l}), \mathrm{C}_{b}$ of chlorophyll $b(\mathrm{mg} / \mathrm{l})$ and the total content of chlorophylls was calculated as the sum of chlorophyll $a$ and chlorophyll $b$ (mg/l).

$$
\begin{aligned}
& C_{\beta-\text { car }}=17.16 \mathrm{~A}_{495}-3.96 \mathrm{~A}_{480} \\
& C_{\text {lut }}=11.51 \mathrm{~A}_{480}-20.61 \mathrm{~A}_{495}
\end{aligned}
$$

where $\mathrm{A}$ is absorption of the solution at 480 and $495 \mathrm{~nm}, C_{\beta-\text { car }}$ is the concentration of $\beta$-carotene $(\mathrm{mg} / \mathrm{l}), \mathrm{C}_{\text {lut }}$ of lutein $(\mathrm{mg} / \mathrm{l})$ and the content of carotenoids was the sum of $\beta$-carotene and lutein (mg/l).

The chlorophyll $a / b$ and the Car/Chl ratio was calculated from $\mathrm{C}_{a}$ and $\mathrm{C}_{b}$ and from the total content of chlorophylls and carotenoids, respectively.

\section{Standard laboratory germination test}

Standard laboratory germination tests were performed in four replicates of 50 seeds each. The seeds were laid on moistened filter papers (Whatman, Grade 1) in Petri dishes (a $14 \mathrm{~cm}$ ). Germination tests were carried out in all samples at $20 / 30{ }^{\circ} \mathrm{C}$ in a $16 / 8$ hours light/dark cycle in a growth chamber, and the duration of the tests for every tested species was given by the CISTA methodology (2014). During the germination tests were evaluated energy of germination and subsequently the total germination with normal developed seedlings, abnormal seedling and dead seeds enumerated according to CISTA (2014).

\section{Emergence test}

Emergence tests were performed in four replicates of 50 seeds each. Seeds were sown 1-2 cm deep in Substrate for sowing and plantlets (Gramoflor GmbH and Co. KG, Germany). Emergence tests were carried out at $20 \pm 3{ }^{\circ} \mathrm{C}$ for 18 days in the greenhouse. Emergence was determined by the appearance of the cotyledons above the compost surface, which were counted daily. Total emergence with normally emerged seedlings were evaluated after 14 days for carrot, 21 days for celery, 28 days for dill, parsley and parsnip according to standard laboratory germination tests (CISTA, 2014).

\section{Statistical analysis of data}

All obtained data were statistically processed using the STATISTICA 12 (StatSoft CZ, Inc.) and Analysis of Variance (ANOVA) test at the level of significance $\alpha=0.05$.

\section{RESULTS AND DISCUSSION}

In a set of commercially available seed samples the content of chlorophylls and carotenoids was evaluated by measuring spectrophotometric characteristics. It was determined that the content of chlorophyll $a$ and $b$ differed between varieties in four species of the plant family Apiaceae (Fig. 1.A, $\mathrm{B}, \mathrm{D}, \mathrm{E})$, and only in one of the species, dill, there were no differences between varieties (Fig. 1.C). With the exception of varieties carrot "Olympus", celery "Nuget", parsley "Atika" and "Orbis" where the values of chlorophyll $a$ and $b$ were very similar (Fig. 1. A, B, D) in all other varieties the amount of chlorophyll $a$ was higher than the value of chlorophyll $b$ as well as the results of Smolikova et al. (2011) in seeds of other species such as carrot, galega, lupine, maize, rape, vetch, soybean. The highest differences in the amount of chlorophylls among varieties of the same species was observed in parsley, where the variety "Olomoucka dlouha" contained the highest values of chlorophyll $a$ and $b$ (75.63 and 51.35 dry wt $\mu g / g$, resp.) and varieties "Atika" and "Orbis" contained very low amounts of chlorophyll $a$ and $b$ (3.44 and 3.00, 3.70 and $2.92 \mathrm{\mu g} / \mathrm{g}$ dry wt in var. "Atika" and "Orbis", resp.) (Figure 1. B, D). The lowest amount of chlorophyll $a$ and $b$ (1.39 and $0.84 \mu \mathrm{g} / \mathrm{g}$ dry wt) were found in seeds of celery "Nuget". The calculated total content of chlorophylls ranged in studied species of Apiaceae from 126.98 to $2.23 \mu \mathrm{g} / \mathrm{g}$ dry wt similarly like in other species such as cabbage, carrot, lupine, maize, pea, rapeseed, soybean, vetch ranging from 51.73 to $0.35 \mu \mathrm{g} / \mathrm{g}$ dry wt (Bulda et al., 2008). Another method, which is based on the measurement of fluorescence signal of chlorophyll $a$ in the seed coat, determined only qualitatively both low and high chlorophyll a content in seeds of cabbage and tomato (Jalink et al., 1998; Jalink et al., 1999). In varieties of cabbage and carrot was proven that physical sanitation of seeds against pathogen infection was more effective in less mature seeds and thus sorting of seeds by their level of chlorophyll fluorescence as a marker of seed maturity provide an useful method for raising efficiency of this treatment (Groot et al., 2006).

The chlorophyll $a / b$ ratio depends on the stage of maturity of the seed. The chlorophyll $a / b$ ratio in canola approximately doubled as canola seed ripened from physiologically mature green $(1: 1$ to $2: 1$ ) to full maturity (2:1 till $4: 1)$. It has been found that chlorophyll $b$ degrades faster than chlorophyll a (Ward et al., 1994a). In this study on Apiaceae species, the chlorophyll $a$ content is higher than the chlorophyll $b$ content, however, the ratio was close to $1: 1$, except for parsley "Olomoucka dlouha", celery "Jemny", dill "Moravan" with a ratio of $1.5: 1$ and celery "Malachit", "Nuget" with a ratio of $1.7: 1$ (Fig. 4). This results are in accordance with chlorophyll $a / b$ ratios for two carrot varieties $1: 1$ ratio and the ratio for canola varieties was found also much higher $2: 1$ to $2.7: 1$ ratio (Bulda et al., 2008). Moreover, chlorophyll $a$ and $b$ contents determined in the two carrot varieties (chlorophyll $a: 26.31$ and 9.62 and chlorophyll $b: 25.42$ and $10.29 \mu \mathrm{g} / \mathrm{g}$ dry wt) (Bulda et al., 2008) give the same absolute values and ratios of chlorophyll $a$ and $b$ as in our study. 
Significant differences were also found in the content of $\beta$-carotene and lutein between varieties of Apiaceae species, with the exception of the content of $\beta$-carotene in dill varieties (Fig. 2.A-E). This study shows that the content of $\beta$-carotene was higher than the value of lutein in most cases. Only the varieties of carrot "Jitka", "Jolana", "Marion" and parsley "Olomoucka dlouha" had a higher lutein content. In addition, the $\beta$-carotene and lutein content in carrot "Olympus" were similar (Figure 2. A, D). Smolikova et al. (2011) also found that $\beta$-carotene occurs in much lower levels than lutein in the seeds of carrot and other species. In another study $\beta$-carotene content of 4.36 and 2.39 and lutein 7.79 and $2.81 \mu \mathrm{g} / \mathrm{g}$ dry wt were detected in two carrot varieties tested (Bulda et al., 2008) indicating again that in carrot the levels of carotene is higher or similar to lutein content. The highest amount of $\beta$-carotene $(21.87 \mu \mathrm{g} / \mathrm{g}$ dry $\mathrm{wt}$ ) and
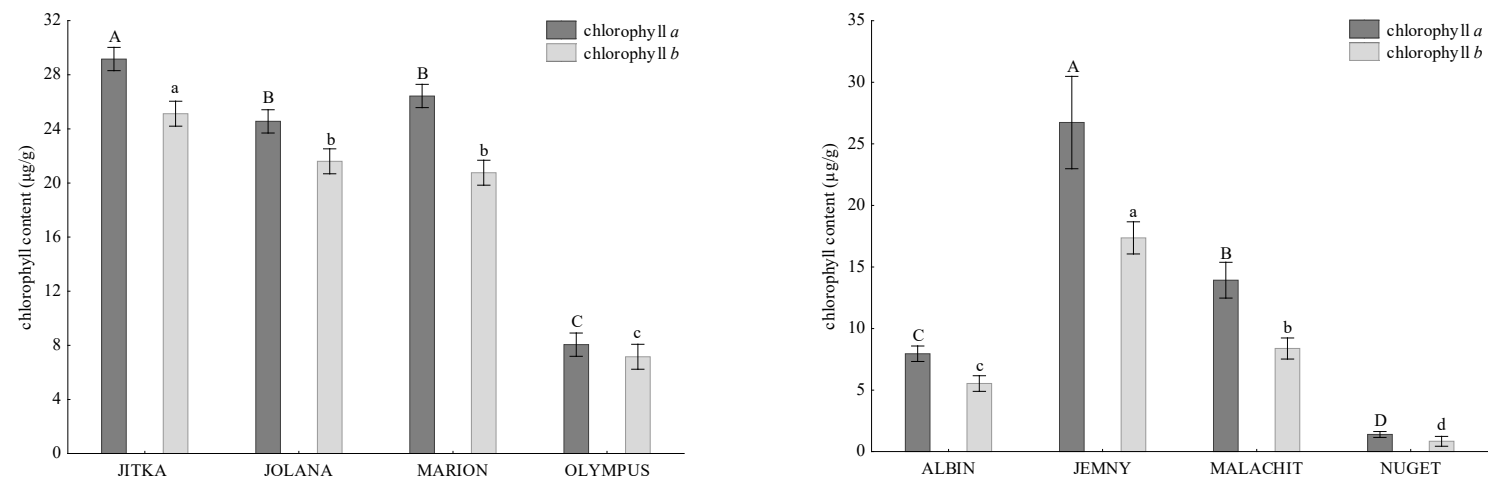

A carrot variety

B

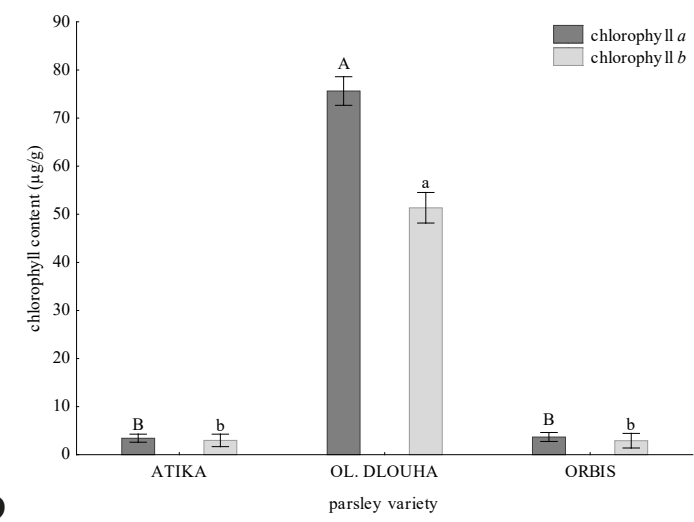

C

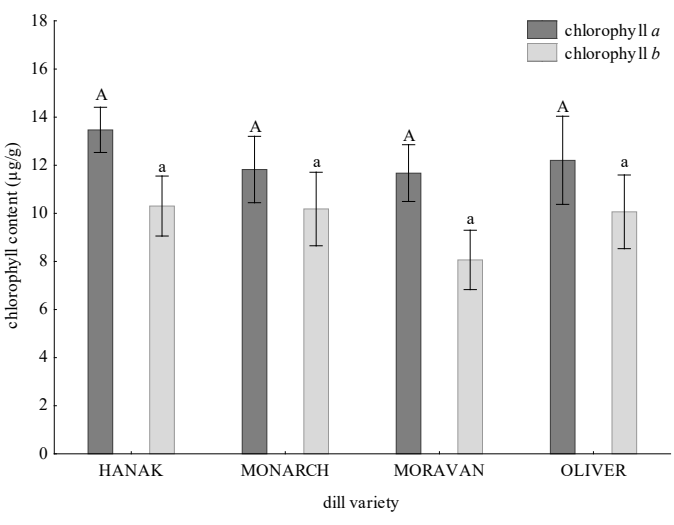

D

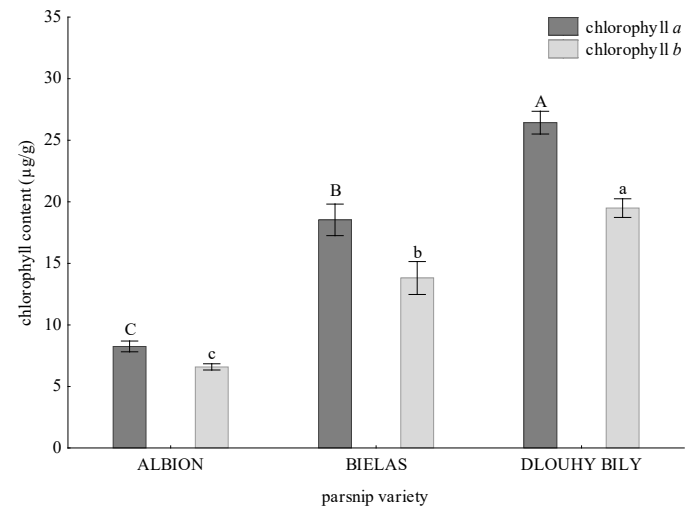

1: Comparison of the content of chlorophyll a and chlorophyll b $(\mu \mathrm{g} / \mathrm{g}$ dry weight) in seeds of carrot (A), celery (B), dill (C), parsley (D) and parsnip (E) varieties

Capital letters above each column represent statistical differences between varieties for chlorophyll $a$, while lower case letter stand for chlorophyll $b$. 
lutein $(22.68 \mu \mathrm{g} / \mathrm{g}$ dry wt) were detected in the seeds of parsley "Olomoucka dlouha" and the lowest amount of $\beta$-carotene ( $2.83 \mu \mathrm{g} / \mathrm{g}$ dry wt) and no lutein were detected in seeds of celery "Nuget". Very low amount of lutein was present in the seeds of parsley "Atika" and "Orbis" (0.19 and $0.63 \mu \mathrm{g} / \mathrm{g}$ dry wt, resp.). Low content of $\beta$-carotene was present in the seeds of celery "Albin" and of parsley "Atika" (3.26 and $3.56 \mu \mathrm{g} / \mathrm{g}$ dry wt, resp.) (Fig. 2. B, D). The determination of the content of carotenoids using spectrophotometric methods performed in previous studies also differed significantly from 16.86 to $0.86 \mu \mathrm{g} / \mathrm{g}$ dry wt (Bulda et al., 2008).

The comparison of the total content of chlorophylls and carotenoids, as the sum of chlorophyll $a$ and $b$, and sum of $\beta$-carotene and lutein resp., indicated that the total chlorophyll content was significantly higher than the carotenoids content of the species and varieties of the plant family Apiaceae. An exception was celery
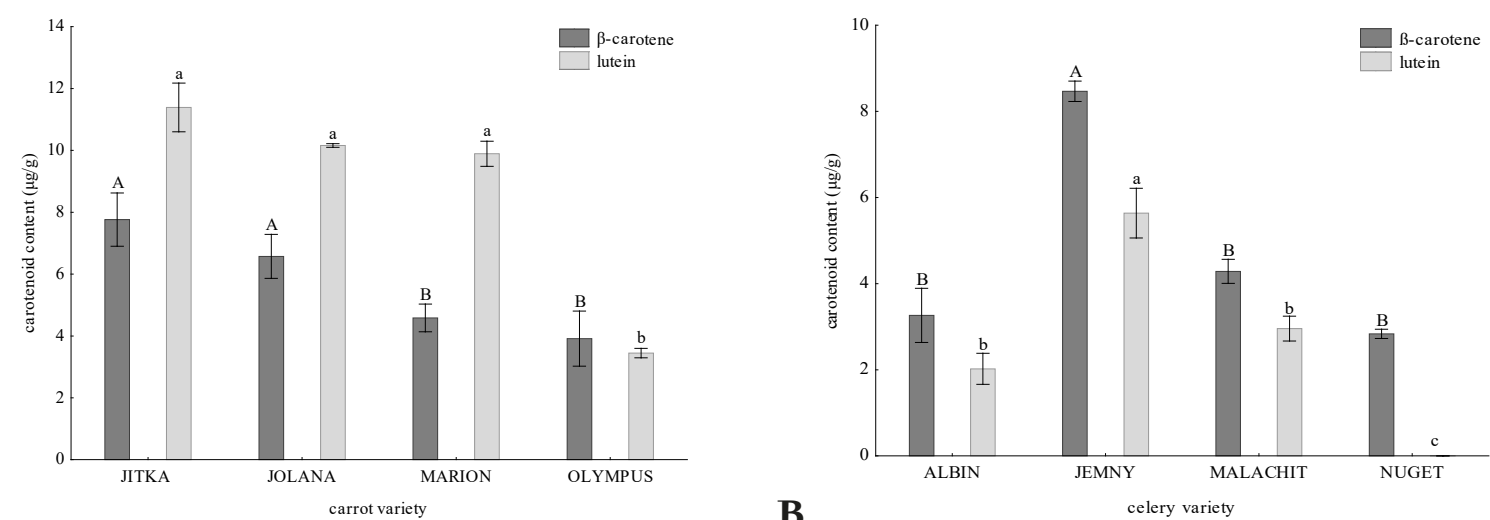

A
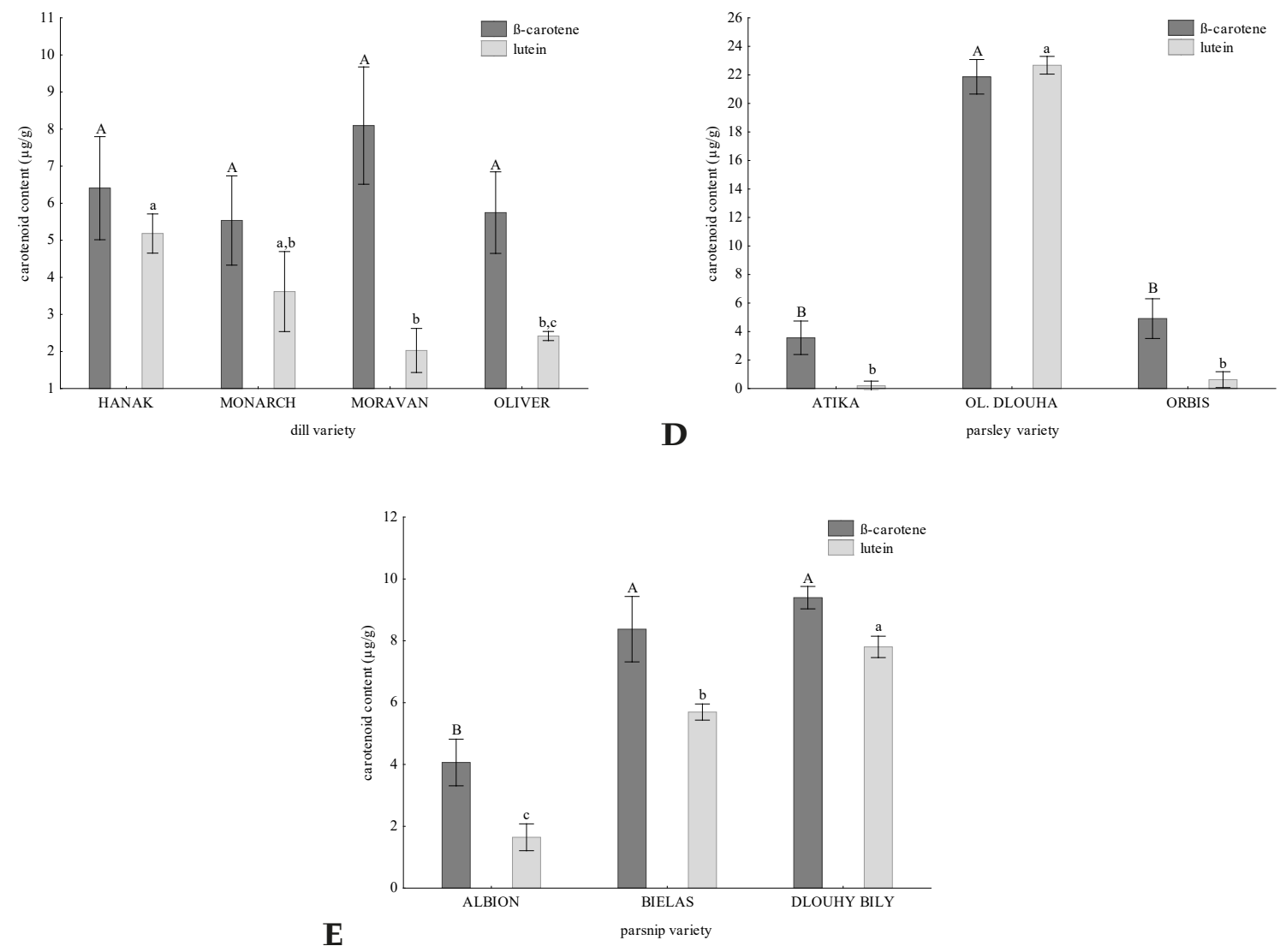

2: Comparison of the content of $\beta$-carotene and lutein ( $\mu \mathrm{g} / \mathrm{g} d r y$ weight) in seeds of carrot (A), celery (B), dill (C), parsley (D) and parsnip (E) varieties

Capital letters above each column represent statistical differences between varieties for $\beta$-carotene, while lower case letter stand for lutein. 
"Nuget" with $2.23 \mu \mathrm{g} / \mathrm{g}$ dry wt of chlorophylls and $2.83 \mu \mathrm{g} / \mathrm{g}$ dry wt of carotenoids. The total content of chlorophyll differs significantly, ranging from $126.98 \mu \mathrm{g} / \mathrm{g}$ to $2.23 \mu \mathrm{g} / \mathrm{g}$ dry wt and the total content of carotenoids ranged from $44.55 \mu \mathrm{g} / \mathrm{g}$ to $2.83 \mu \mathrm{g} / \mathrm{g}$ dry wt (Fig. 3.A-E, Fig. 4). Because most samples contained much more chlorophylls than carotenoids, determined ratios of Car/Chl were around 0.4. The only value Car/Chl ratio higher than 1 (1.3) was observed in seeds of celery "Nuget" (Fig. 4). For carrot varieties were also found similarly low Car/Chl ratios, but most of other studied species from other plant families have the ratio higher than 1 reaching 9.5 in lupine (Bulda et al., 2008; Smolikova et al., 2011).

The standard laboratory germination tests were performed for all of the varieties according to CISTA (2014) as a seed quality parameter. Within the varieties of species, significant differences were found only in carrots, where the lower germination $82 \%$ in "Jolana" was found as statistically significant. Overall, a lower germination rate of about $80 \%$ was
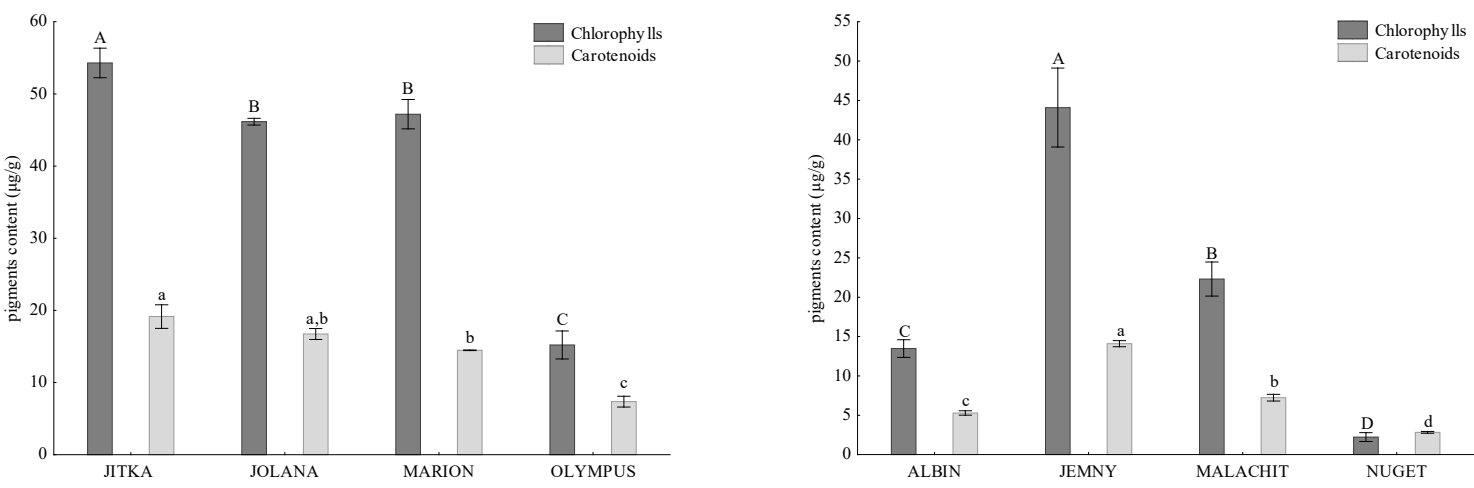

A

carrot variety

B
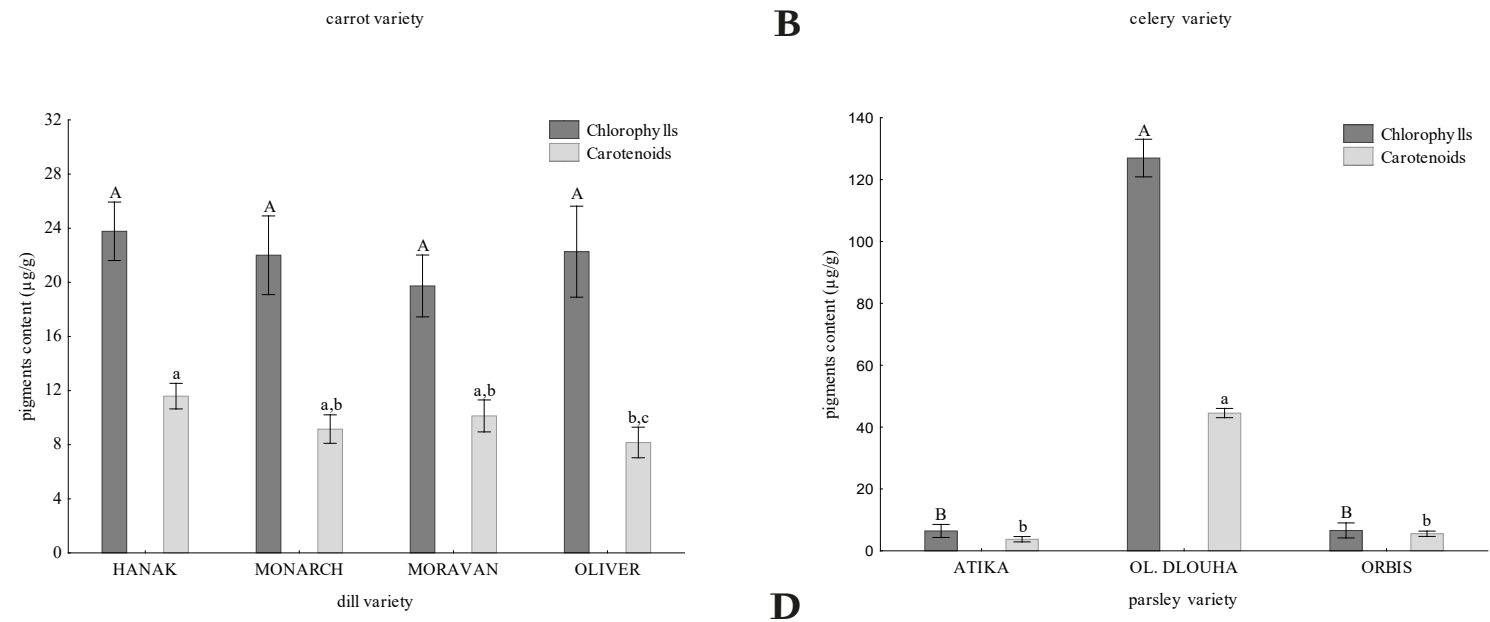

D

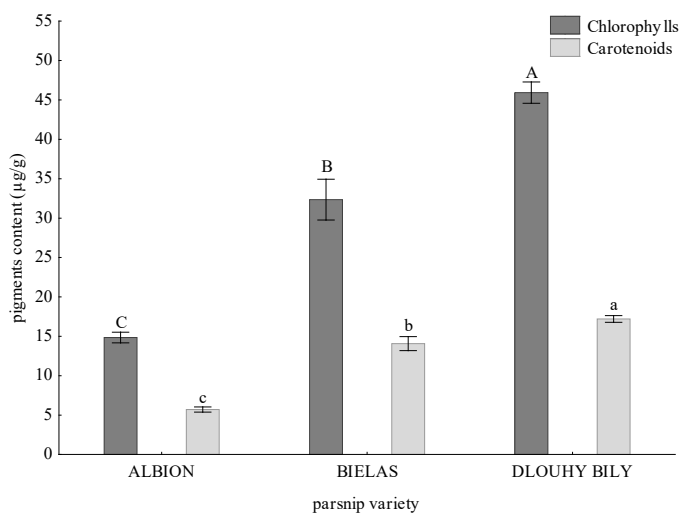

3: Comparison of the content of chlorophylls and carotenoids ( $\mu \mathrm{g} / \mathrm{g}$ dry weight) in seeds of carrot (A), celery (B), dill (C), parsley (D) and parsnip (E) varieties

Capital letters above each column represent statistical differences between varieties for chlorophylls, while lower case letter stand for carotenoids. 
observed for celery. The energy of germination was more diverse and with the exception of dill varieties in all species the highest and lowest result was statistically significant (Fig. 4). The carrot germination value of about $80 \%$ was found in variety of "Brasilia" in physiological maturity (35 DAA), and it has grown to full maturity even slightly. The value of energy of germination was only around $60 \%$ (Miranda et al., 2017), but in our results it was higher around $87 \%$, except "Jolana" with only $77 \%$. In the case of parsley variety "Lisa Preferida", represented by four commercial lots, $62-63 \%$ germination was lower than the minimum recommended for certified seed commercialization $(80 \%)$ and energy of germination had values $51-56 \%$. Sorting seeds by coloration of mericarps enabled to reach in some cases germination values from $80 \%$ to $88 \%$, and energy of germination ranged from $46 \%$ to $62 \%$ (Oliveira et al., 2013). In our results, the germination values reached the minimum recommended for certified seed commercialization and energy of germination ranged from 65 to $90 \%$.

Another followed seed quality parameter was seedling emergence, which has shown statistically significant differences among varieties in all species studied, what was in the case of germination energy also in all species except dill and germination was statistically different only among carrot varieties. Also then range of seedling emergence values was very broad from celery var. "Albin" with only $15 \%$ till $92 \%$ reached by three varieties of two different species (carrots "Jitka" and "Olympus", parsnip "Dlouhy bily") (Fig. 4). The largest difference between seedling emergence and germination was observed for the celery varieties, where the seedling emergence reached only $40 \%$. Seedling emergence of carrot variety "Brasilia" was around 80\% from 28 DAA to 63 DAA (Miranda et al., 2017), but in our results carrot varieties show values around $89 \%$, except "Jolana" with $77 \%$. In the case of parsley variety "Lisa Comum", where four seed lots were used, values of seedling emergence ranged from 48-81\% (Tunes et al., 2013). The range of seedling emergence of our 3 parsley varieties was not as wide and ranged from $65-78$ \% (Fig. 4).

The standard laboratory germination tests of the varieties were used for correlation with the measured pigment contents in the seeds. There was no correlation between germination rate and the total content of chlorophylls in the analyzed seeds of species (data not shown). Although the coefficient $\left(\mathrm{r}^{2}\right)$ of parsley and parsnip (0.6768 and 0.5916, resp.) shows middle negative correlation, there is no statistically significant difference between the individual germination of varieties (Fig 4). A similar trend was observed between germination rate and the content of lutein, where no dependence was found, but the coefficient of parsley and parsnip (0.6916 and 0.6950, resp.) shows negative correlation and coefficient of dill (0.4702) had a positive correlation (data not shown), but they are not statistically significant (Fig 4). Previous studies, based on measured chlorophyll fluorescence (CF) signal, demonstrated a negative correlation with germination rate such as for white cabbage of variety Eldorado, which were sorted individually based on the chlorophyll fluorescence signal and the results show that the magnitude of the CF signal was inversely related to the quality of the seeds, expressed as germination rate. Seeds from the subsample with the lowest CF signal had the highest germination rate (100\%), but in comparison to the low, medium and high CF subsamples had significantly reduced performance of germination (Jalink et al., 1998). Similar dependence, when the subsample with the highest CF intensity resulted in the lowest quality and the quality increased with decreasing CF signal, was also monitored by another white cabbage cultivar Stardon Fl Hybrid (Jalink et al., 1999).

\begin{tabular}{|c|c|c|c|c|c|c|c|c|c|c|c|c|}
\hline Species & Variety & Chlorophyll $a$ & Chlorophyll $b$ & Chl $a / b$ & Chlorophylls & $\beta$-carotene & Lutein & Carotenoids & $\mathrm{Car} / \mathrm{Chl}$ & $\mathrm{G}$ & $\mathrm{Eg}$ & SE \\
\hline \multirow[t]{3}{*}{ Carrot } & JITKA & 29.17 & 25.13 & $1.2: 1$ & 54.29 & 7.76 & 11.39 & 19.15 & 0.4 & $91 \mathrm{a}$ & $86 \mathrm{a}$ & $92 \mathrm{a}$ \\
\hline & JOLANA & 24.56 & 21.60 & $1.1: 1$ & 46.16 & 6.57 & 10.16 & 16.73 & 0.4 & $82 \mathrm{~b}$ & $77 \mathrm{~b}$ & $66 \mathrm{~b}$ \\
\hline & MARION & 26.43 & 20.74 & $1.3: 1$ & 47.20 & 4.58 & 9.89 & 14.48 & 0.3 & $88 \mathrm{ab}$ & $87 \mathrm{a}$ & $84 \mathrm{a}$ \\
\hline \multirow[t]{3}{*}{ Celery } & ALBIN & 7.95 & 5.54 & $1.4: 1$ & 13.49 & 3.26 & 2.02 & 5.29 & 0.4 & $98 \mathrm{a}$ & $96 \mathrm{a}$ & $15 \mathrm{~b}$ \\
\hline & JEMNY & 26.74 & 17.36 & $1.5: 1$ & 44.10 & 8.47 & 5.64 & 14.10 & 0.3 & $94 \mathrm{a}$ & $93 a b$ & $34 \mathrm{a}$ \\
\hline & MALACHIT & 13.93 & 8.38 & $1.7: 1$ & 22.31 & 4.29 & 2.96 & 7.24 & 0.3 & $94 a$ & $91 \mathrm{ab}$ & $36 \mathrm{a}$ \\
\hline \multirow[t]{4}{*}{ Dill } & HANAK & 13.47 & 10.30 & $1.3: 1$ & 23.77 & 6.41 & 5.18 & 11.59 & 0.5 & $82 \mathrm{a}$ & $81 \mathrm{a}$ & $71 \mathrm{~b}$ \\
\hline & MONARCH & 11.82 & 10.18 & $1.2: 1$ & 22.00 & 5.54 & 3.62 & 9.15 & 0.4 & $84 \mathrm{a}$ & $80 \mathrm{a}$ & $83 a$ \\
\hline & MORAVAN & 11.67 & 8.06 & $1.5: 1$ & 19.74 & 8.10 & 2.03 & 10.12 & 0.5 & $79 \mathrm{a}$ & $72 \mathrm{a}$ & $85 \mathrm{a}$ \\
\hline & OLIVER & 12.20 & 10.06 & $1.2: 1$ & 22.67 & 5.75 & 2.42 & 8.17 & 0.4 & $79 \mathrm{a}$ & $76 \mathrm{a}$ & $82 \mathrm{a}$ \\
\hline \multirow[t]{2}{*}{ Parsley } & ATIKA & 3.44 & 3.00 & $1.2: 1$ & 6.44 & 3.56 & 0.19 & 3.76 & 0.6 & $92 \mathrm{a}$ & $90 \mathrm{a}$ & $65 \mathrm{~b}$ \\
\hline & OL.DLOUHA & 75.63 & 51.35 & $1.5: 1$ & 126.98 & 21.87 & 22.68 & 44.55 & 0.4 & $85 \mathrm{a}$ & $65 \mathrm{~b}$ & $78 \mathrm{a}$ \\
\hline Parsnip & DL.BILY & 26.43 & 19.49 & $1.4: 1$ & 45.93 & 9.40 & 7.80 & 17.20 & 0.4 & $90 \mathrm{a}$ & $77 \mathrm{~b}$ & $92 \mathrm{a}$ \\
\hline
\end{tabular}

4: Content of chlorophyll, carotenoids ( $\mu \mathrm{g} / \mathrm{g} d r y$ weight), and seed quality parameters (\%) of carrot, celery, dill, parsley and parsnip varieties Chlorophylls (Chl), Carotenoids (Car), Germination (G), Energy of germination (Eg), Seedling emergence (SE). Letters represent statistical differences between varieties of carrot, celery, dill, parsley and parsnip. 

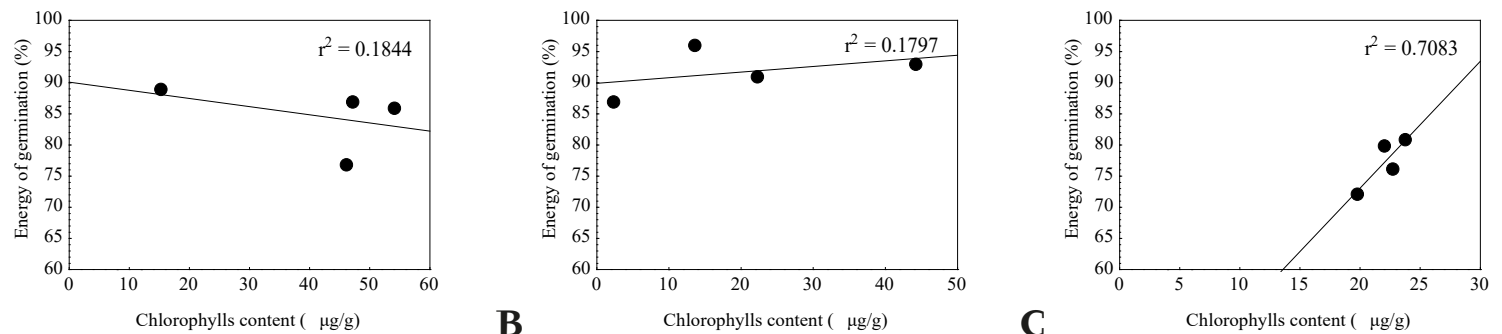

A

B
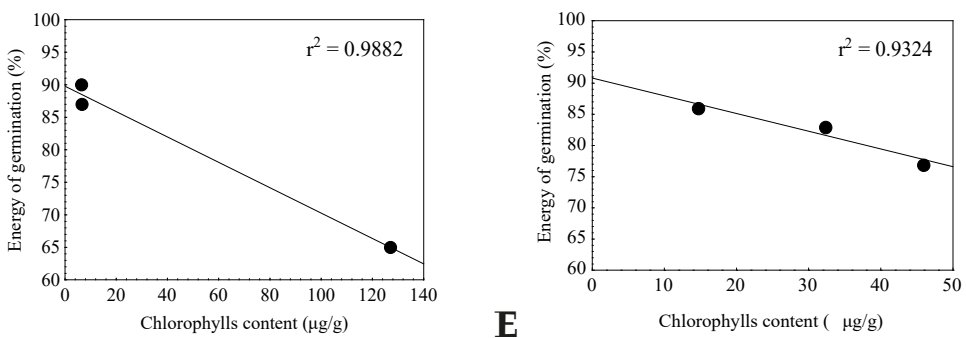

5: Effect of the total content of chlorophylls on the energy of germination in carrot (A), celery (B), dill (C), parsley (D) and parsnip (E) varieties

A

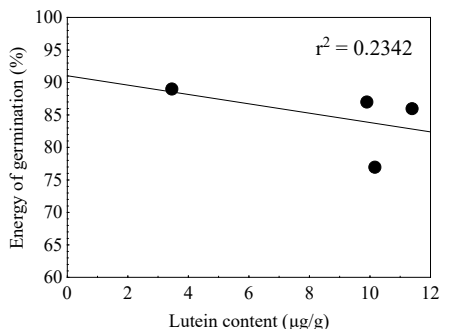

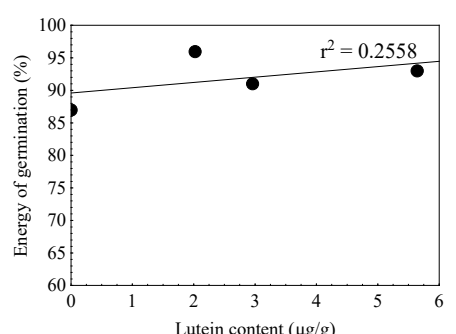

B

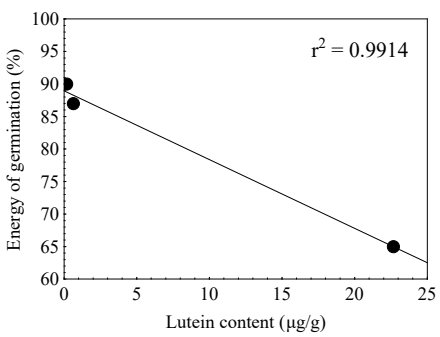

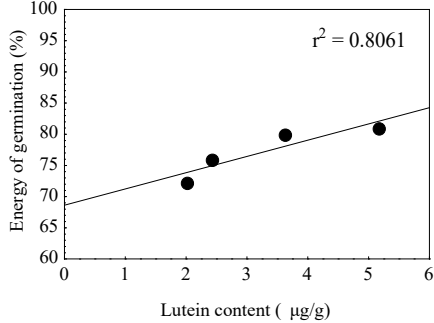

C

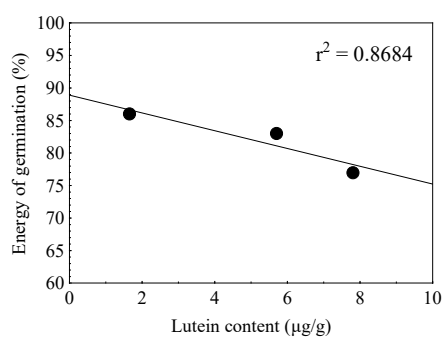

6: Effect of the content of lutein on the energy of germination in carrot (A), celery (B), dill (C), parsley (D) and parsnip (E) varieties

There was a statistically significant negative correlation for the energy of germination and the total content of chlorophylls and of lutein for parsley with high values of $\mathrm{r}^{2}(0.9882$ and 0.9914 , resp.) and for parsnip (0.9324 and 0.8684, resp.). Higher $\mathrm{r}^{2}$ value is also present for positive correlation for dill (0.7083 and 0.8061, resp.), although there is no statistical difference between the individual values of energy of germination (Fig 4). Low coefficients were found in species of carrot and celery (Fig. 5. A-E and Fig. 6.A-E). Exactly opposite correlation of seedling emergence and the total content of chlorophylls and of lutein compared with results for energy of germination were obtained. That means that there is positive correlation between seedling emergence and the total content of chlorophyll and of lutein for parsley with values of $\mathrm{r}^{2}$ (0.7117 and 0.7260 , resp.) and for parsnip (0.8343 and 0.9063, resp.). Because there are statistically significant differences in values of seedling emergence of dill varieties, there is negative correlation between seedling emergence and the total content of chlorophyll and of lutein $\left(\mathrm{r}^{2}\right.$ 0.6525 and 0.8108 , resp.) (Fig. 7.A-E and Fig. 8. A-E) and no correlation was found in carrot and celery. Germination and seedling emergence was used in a previous study to determine the efficacy of chlorophyll fluorescence sorting in pepper seed lots, and in both negative correlation was observed, because removal of seeds with high CF signal has 

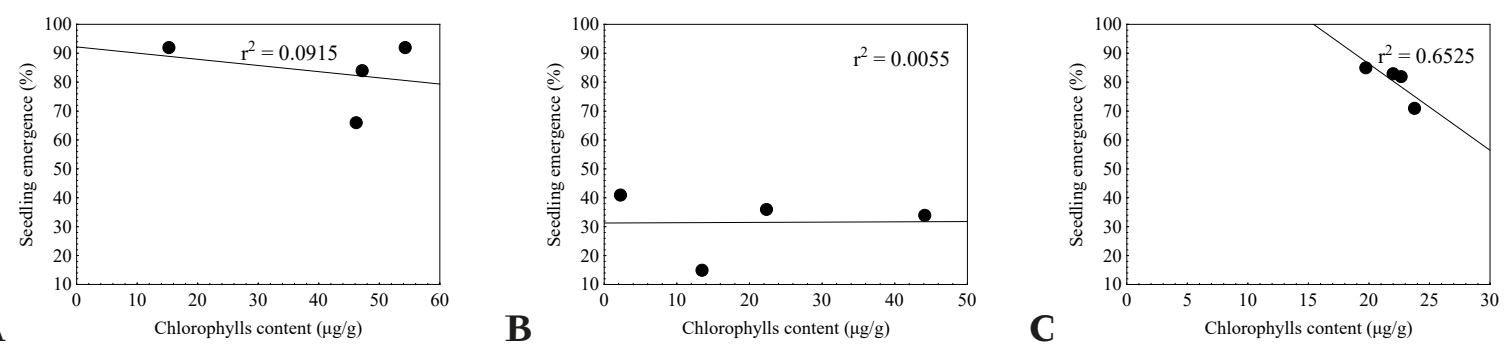

\section{A}
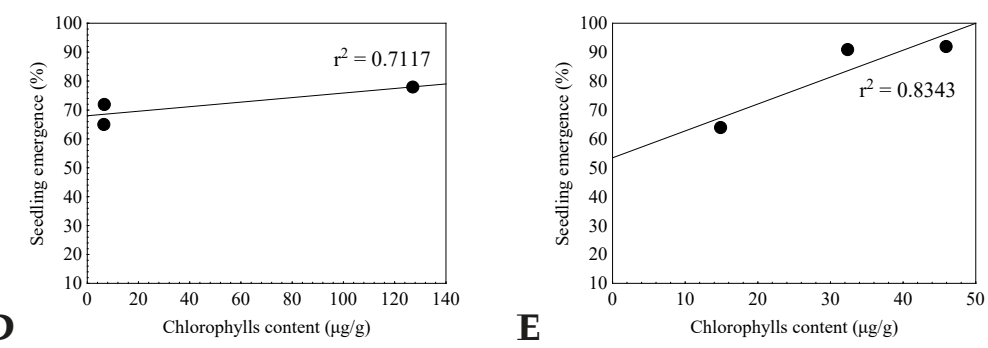

7: Effect of the total content of chlorophyll on the seedling emergence in carrot (A), celery (B), dill (C), parsley (D) and parsnip (E) varieties
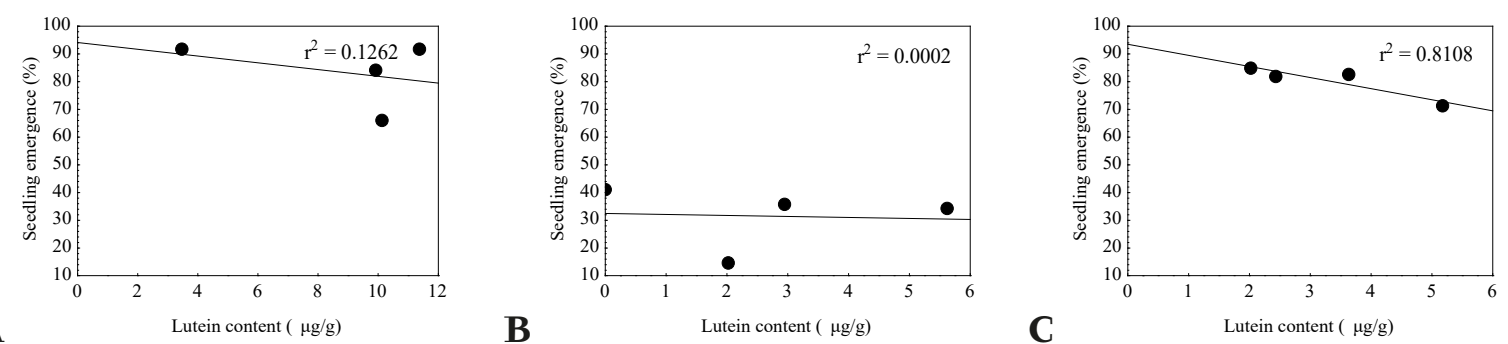

A

B
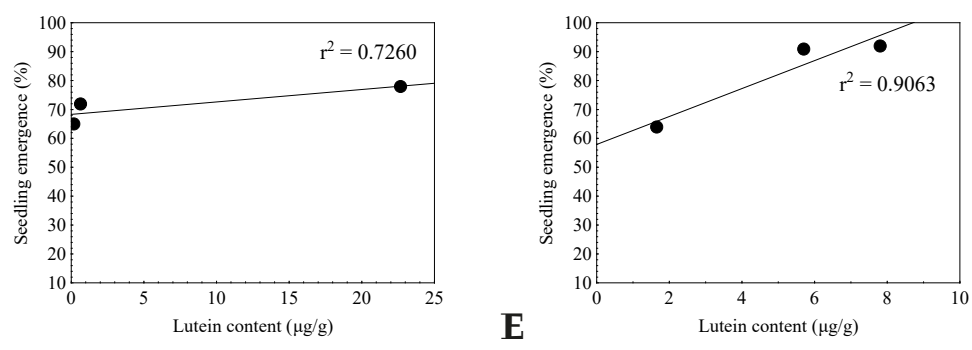

8: Effect of the content of lutein on the seedling emergence in carrot (A), celery (B), dill (C), parsley (D) and parsnip (E) varieties

significantly increased laboratory germination and also seedling emergence for three of the four pepper varieties (Kenanoglu et al., 2013), while in another study CF sorting did not enhance the seedling potential and vigor of commercial seed lots of tomato and cucumber to increase laboratory germination. However, its effect was more prominent on emergence potential (Demir et al., 2013) like in our study.

\section{CONCLUSION}

In this study, it was confirmed that spectrophotometry can be used to determine the content of pigments, namely chlorophylls-chlorophyll $a$ and $b$, and carotenoids - $\beta$-carotene and lutein in the seeds of commercial varieties from the plant family Apiaceae. That the ratio of contents of carotenoids to chlorophylls (Car/Chl) could be a measure of seed tolerance to abiotic stresses, because carotenoids are considered as antioxidants that function to protect the seeds against oxidative stress was proposed by Smolikova et al. (2011). From this, it could be concluded that higher levels of stress tolerance can be found in higher ratios of Car/Chl, which in case of the studied set of varieties from the family Apiaceae was fulfiled only by celery var. "Nuget". This assumption, however, must 
be supported by other tests that would mimic stressful conditions. Consequently, the correlation between the content of individual pigments and seed quality parameters was observed and resulted in negative correlation between energy of germination and pigments in parsley and parsnip varieties and between seedling emergence and pigments in dill varieties. Further positive correlation was observed in the parsnip and parsley varieties between seedling emergence and pigments. In future studies, the content of pigments, germination energy and seedling emergence should be determined for a larger set of varieties to verify the correlations observed in this study to prove the possibility to use spectrophotometry to evaluate the pigments present in the seeds as an indicator of seed quality.

\section{Acknowledgements}

This research was financially supported by the IGA FA MENDELU No. IP 5/2017. Acknowledgments belong to SEMO, Smržice, Inc. And MORAVOSEED CZ, Mikulov, Inc. for providing seeds. The authors thank professor Amanda J. Deering (Purdue University, Indiana, USA) for her critical reading and English proofreading of the manuscript. Experiments and analyses were performed in new Biotechnology Pavilion M at Mendel University which was built in the frame of OP VaVpI CZ.1.05/4.1.00/04.0135 project.

\section{REFERENCES}

BEWLEY, J. D., BRADFORD, K. J., HILHORST, H. W. M. et al. 2013. Seeds: Physiology of Development, Germination and Dormancy. $3^{\text {rd }}$ Edition. New York: Springer Science \& Business Media.

BULDA, O. V., RASSADINA, V. V., ALEKSEICHUK, H. N. And LAMAN, N. A. 2008. Spectrophotometric measurement of carotenes, xanthophylls and chlorophylls in extracts from plant seeds. Russ. J. Plant Physiol., 55(4): 544-551.

CENTRAL INSTITUTE FOR SUPERVISING AND TESTING IN AGRICULTURE (CISTA). 2014. Methodology of seed and seed testing. [in Czech: Metodika zkoušení osiva a sadby]. [Online]. Available at: http://www.apicak.cz/ data_ak/14/v/MetZkouseniOsivaSadby.pdf [Accessed: 2017, June 5].

CICERO, S. M., SCHOOR, R. And JALINK, H. 2009. Use of chlorophyll fluorescence sorting to improve soybean seed quality. Rev. Bras. Sementes, 31(4): 145-151.

DEMIR, I., KENANOGLU, B. B., JALINK, H. And MAVI, K. 2013. Chlorophyll fluorescence sorting method to improve seedling emergence potential and vigour of commercial tomato and cucumber seed lots. Int. J. Agric. For., 3(7): 333-338.

GREEN, B. R., SINGH, S., BABIC, I., BLADEN, C. And JOHNSON-FLANAGAN, A. M. 1998. Relationship of chlorophyll, seed moisture and ABA levels in the maturing Brassica napus seed and effect of a mild freezing stress. Physiol. Plant., 104: 125-133.

GROOT, S.P.C., BIRNBAUM, Y., ROP, N., JALINK, H., FORSBERG, G., KROMPHARDT, C., WERNER, S. And KOCH, E. 2006. Effect of seed maturity on sensitivity of seeds towards physical sanitation treatments. Seed Sci. G Technol., 34: 403-413.

HERCHI, W., SAKOUHI, F., BOUKHCHINA, S., KALLEL, H. And PEPE, C. 2011. Changes in fatty acids, tocochromanols, carotenoids and chlorophylls content during flaxseed development. J. Am. Oil Chem. Soc., 88: 1011-1017.

INTERNATIONAL SEED TESTING ASSOCIATION (ISTA). 1996. International rules for seed testing. Supplement to Seed Sci. 6 Technol., 21: 1-288.

JALINK, H., FRANDAS, A., SCHOOR, R. And BINO, J. B. 1998. Chlorophyll fluorescence of the testa of Brassica oleracea seeds as an indicator of seed maturity and seed quality. Sci. Agric., 55: 88-93.

JALINK, H., SCHOOR, R., BIRNBAUM, Y. E. And BINO, R. J. 1999. Seed chlorophyll content as an indicator for seed maturity and seed quality. Proc. of the Int. Symp., Stand Establishment/Seed, Acta Hort., 504: 219-223.

JING, H. C., BERGERVOET, J. H. W., JALINK, H., KLOOSTER, M., DU, S. L., BINO, R. J., HILHORST, H. W. M. And GROOT, S. P. C. 2000. Cucumber (Cucumis sativus L.) seed performance as influenced by ovary and ovule position. Seed Sci. Res., 10: 435-445.

KENANOGLU, B. B., DEMIR, I. And JALINK, H. 2013. Chlorophyll fluorescence sorting method to improve quality of Capsicum pepper seed lots produced from different maturity fruits. Hort. Science, 48(8): 965-968.

KENANOGLU, B. B., DEMIR, I. And JALINK, H. 2016. Improvement of seed germination performance of stored commercial pepper seed lots with chlorophyll fluorescence sorting method. Am. J. Exp. Agr., 10(4): 1-6.

KONSTANTINOVA, P., VAN DER SCHOOR, R., VAN DEN BULK, R. And JALINK, H. 2002. Chlorophyll fluorescence sorting as a method for improvement of barley (Hordeum vulgare L.) seed health and germination. Seed Sci. $\sigma$ Technol., 30(2): 411-421.

MIRANDA, R. M., DIAS, D. C. F. S., PICOLI, E. A. T., SILVA, P. P. And NASCIMENTO, W. M. 2017. Physiological quality, anatomy and histochemistry during the development of carrot seeds (Daucus carota L.). Ciênc. Agrotec., 41(2): 169-180. 
MONMA, M., TERAO, J., ITO, M., SAITO M. And CHIKUNI, K. 1994. Carotenoid components in soybean seeds varying with seed color and maturation stage. Biosci. Biotechnol. Biochem., 58(5): 926-930.

OLIVEIRA, S. F., COSTA, D. S., MELLO, S. C., NOVEMBRE, A. D. L. C. And GOMES-JUNIOR, F. G. 2013. Germination of parsley seeds influenced by mericarps color and internal morphology. Hortic. bras., 31(2): 231-235.

SINNECKER, P., GOMES, M. S. O., AREAS, J. A. G. And LANFER-MARQUEZ, U. M. 2002. Relationship between color (instrumental and visual) and chlorophyll contents in soybean seeds during ripening. J. Agric. Food Chem., 50: 3961-3966.

SINNECKER, P., BRAGA, N., MACCHIONE, E. L. A. And LANFER-MARQUEZ, U. M. 2005. Mechanism of soybean (Glycine $\max$ L. Merill) degreening related to maturity stage and postharvest drying temperature. Postharvest Biol. Technol., 38: 269-279.

SMOLIKOVA, G. N., LAMAN, N. A. And BORISKEVISCH, O.V. 2011. Role of chlorophylls and carotenoids in seed tolerance to abiotic stressors. Russ. J. Plant Physiol., 58(6): 965-973.

TUNES, L. M., PEDROSO, D. C., GADOTTI, G. I., MUNIZ, M. F. B., BARROS, A. C. S. A. And VILLELA, F. A. 2013. Accelerated aging to assess parsley seed vigor. Hortic. bras., 31(3): 457-460.

WARD, K., SCARTH, R., DAUN, J. K. And THORSTEINSON, C. T. 1994a. Characterization of chlorophyll pigments in ripening canola seed (Brassica napus). J. Am. Oil Chem. Soc., 71(12): 1327-1331.

WARD, K., SCARTH, R., DAUN, J. K. And THORSTEINSON, C. T. 1994b. A comparison of highperformance liquid chromatography and spectrophotometry to measure chlorophyll in canola seed and oil. J. Am. Oil Chem. Soc., 71(9): 931-934.

WARD, K., SCARTH, R., DAUN, J. K. And VESSEY, J. K. 1995. Chlorophyll degradation in summer oilseed rape and summer turnip rape during seed ripening. Can. J. of Plant Sci., 75: 413-420.

WILSON, H. T., KHAN, O. And WELBAUM, G. E. 2014. Chlorophyll fluorescence in developing 'Top Mark' cantaloupe (Cucumis melo) seeds as an indicator of quality. Seed Technol., 36(2): 103-113. 